CURRENT RESEARCH JOURNAL OF PEDAGOGICS 2(12): 166-170,

December 2021 DOI: https://doi.org/10.37547/pedagogics-crjp-02-12-33

ISSN 2767-3278

(C)2021 Master Journals

Crossref dof 81 Google

Accepted 25 th December, 2021 \& Published 30 th December, 2021

\title{
INTELLECTUAL DEVICES FOR DETERMINATION OF DUST PARTICLE CONCENTRATION
}

\author{
Nosir Yusubjanovich Sharibayev \\ Namangan Institute Of Engineering Technology, Uzbekistan \\ Ahror Aminjon Ogli Tursunov \\ Namangan Institute Of Engineering Technology, Uzbekistan \\ Sherzod Sobirjonovich Djurayev \\ Namangan Institute Of Engineering Technology, Uzbekistan
}

\section{ABSTRACT}

The article describes the devices for determining the concept of intellectual dust used in industrial enterprises, workplaces and residential areas and the principle of their operation, and analyzes their operation technology.

KEYWORDS: - Dust concentration, optical (photometric), gravimetric, piezobalance, triboelectric, radioisotope.

\section{INTRODUCTION}

Dust concentration device - a device designed to measure the mass concentration of dust in the exhaust gases of combustion devices, work and living areas, ambient air. A specific type of device must be used for each task [1].

Today, there are several methods of measuring dust: optical (photometric), gravimetric, piezobalance, triboelectric, radioisotope [2].

The gravimetric method of measuring aerosols
(GOST 17.2.4.05-83) consists of separating the particles from the dust and gas stream, then placing them in an analytical filter and drying. The weight gain in the filter, taking into account the sample size, is used to determine the mass concentration of the aerosol. In this case, the dust concentration is calculated using mathematical expressions [7].

Advantages of the gravimetric method:

- The advantage of this method is the accuracy of measurement, because there is a direct measurement of the aerosol and 
CURRENT RESEARCH JOURNAL OF PEDAGOGICS 2(12): 166-170,

December 2021 DOI: https://doi.org/10.37547/pedagogics-crjp-02-12-33

ISSN 2767-3278

(C)2021 Master Journals

Crossief do) 88 Google

Accepted 25 th December, 2021 \& Published 30 th December, 2021

there is no effect of physicochemical properties on the results,

Disadvantages of the gravimetric method:

- The difficulty of this method,

- Duration of the process,

- Use of additional equipment.

The piezo-balanced method of measuring the performance of the device is to periodically take a sample of aerosol particles through a blower, which separates the receiving (up to $10 \mu \mathrm{m}$ ) fractions from the total mass of particles, then charges them with the help of a corona electrode

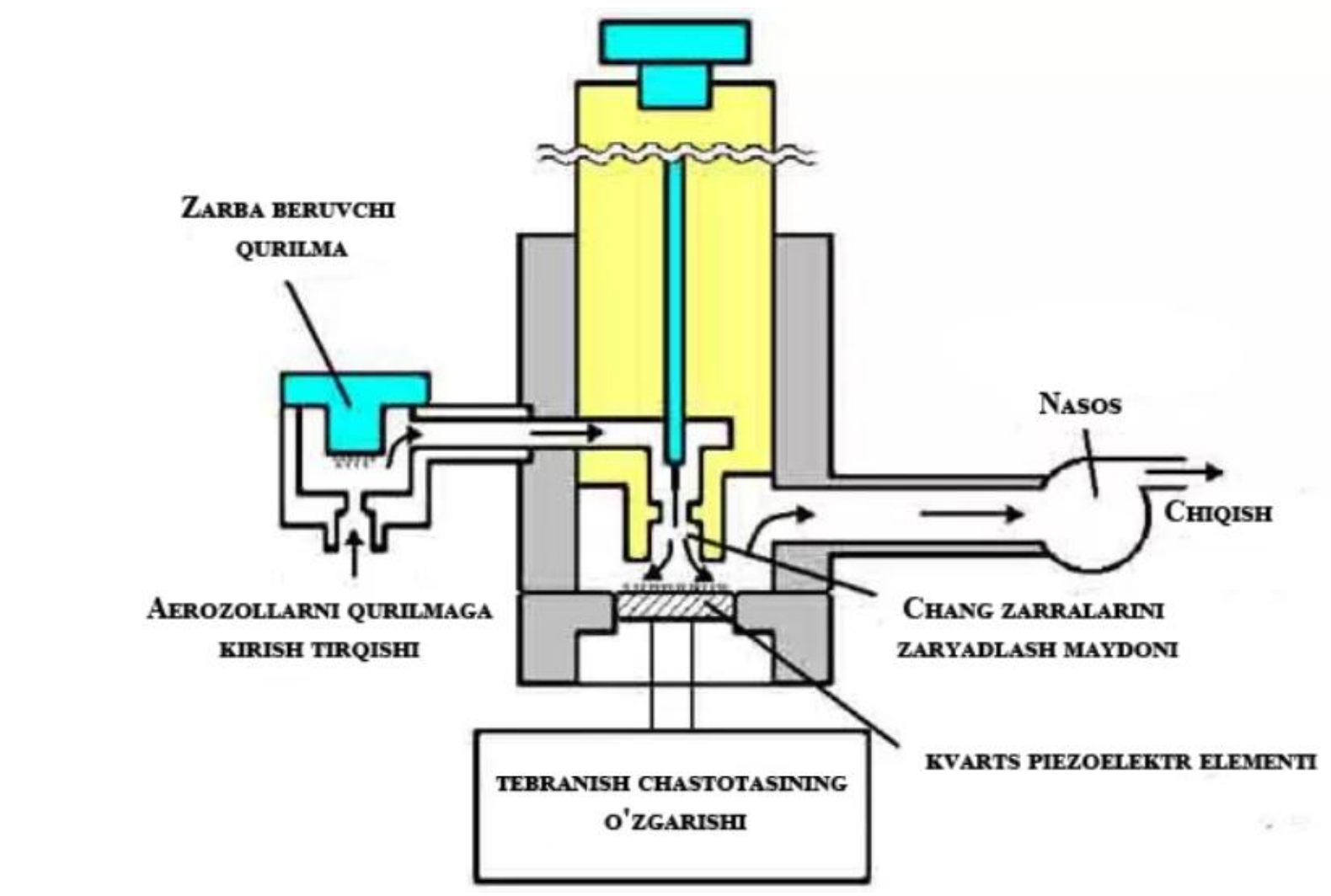

Figure 1. Schematic diagram of gravimetric measuring devices and the collector is placed on the electrode surface. A piezoelectric element (quartz) is used as such an electrode. Sampling is performed by the internal pump of the device. The quartz piezoelectric element is included in the circuit of the electric vibration generator. When dust falls on its surface, the weight of the piezoelectric element and consequently its oscillation frequency change. The linear change in frequency depends on the mass of dust collected in the element and is the value of the measured weight concentration of the aerosol [8]. Figure 1. 
CURRENT RESEARCH JOURNAL OF PEDAGOGICS 2(12): 166-170,

December 2021 DOI: https://doi.org/10.37547/pedagogics-crjp-02-12-33

ISSN 2767-3278

(C)2021 Master Journals

Crossref doi) 81 Google

Accepted 25 th December, 2021 \& Published 30 th December, 2021

Advantages of piezo-balanced measurement method:

- Fast measurements, no need to use a large fleet of additional equipment

- Reliability of instrument readings, physicochemical properties do not affect the measurements

- Small size of the measuring instrument (the instrument is usually delivered in a portable box, the total weight of the instrument does not exceed $4 \mathrm{~kg}$ ).

Disadvantages of the piezo-balanced measurement method:

- Measurement is carried out only in the workplace and residence,

- High cost of equipment,

- Handle with care (the sensitive element of the device is very delicate, do not allow it to fall, and prevention device should be carried out strictly in accordance with the instructions).

The triboelectric measurement method is based on measuring the induced charge on an insulated measuring electrode located in a metal gas channel through which a stream of dust and gas flows. The induced charge results from the interaction of moving aerosol particles with the electrode surface, the value of which is proportional to the aerosol mass concentration over a wide measurement range. These devices are called triboelectric. They can be divided into instruments that measure the DC (digital signal) component of the triboelectric signal and instruments that measure the AC (analog signal) component (electrodynamically induced charge) of the triboelectric signal. DC type measuring devices include Auburn, FilterSense, Babbit and Bindicator (USA). AC type measuring devices include S300 series electrodynamic devices (S301 / S303 / S304 / S305) [9]. Advantages of triboelectric measurement method:

- Vibration at the installation site does not affect the performance,

- Does not have nodes that can be contaminated, which allows the devices to be used for a long time in severe conditions, and it is possible to use them in severe conditions because the signal processing nodes are located outside,

- The device is less likely to lose its resources over time. The devices are durable, so they are simple and inexpensive to maintain. Figure 2 . 
CURRENT RESEARCH JOURNAL OF PEDAGOGICS 2(12): 166-170,

December 2021 DOI: https://doi.org/10.37547/pedagogics-crjp-02-12-33

ISSN 2767-3278

(C)2021 Master Journals

Crossref dof 81 Google

Accepted 25 th December, 2021 \& Published 30 th December, 2021
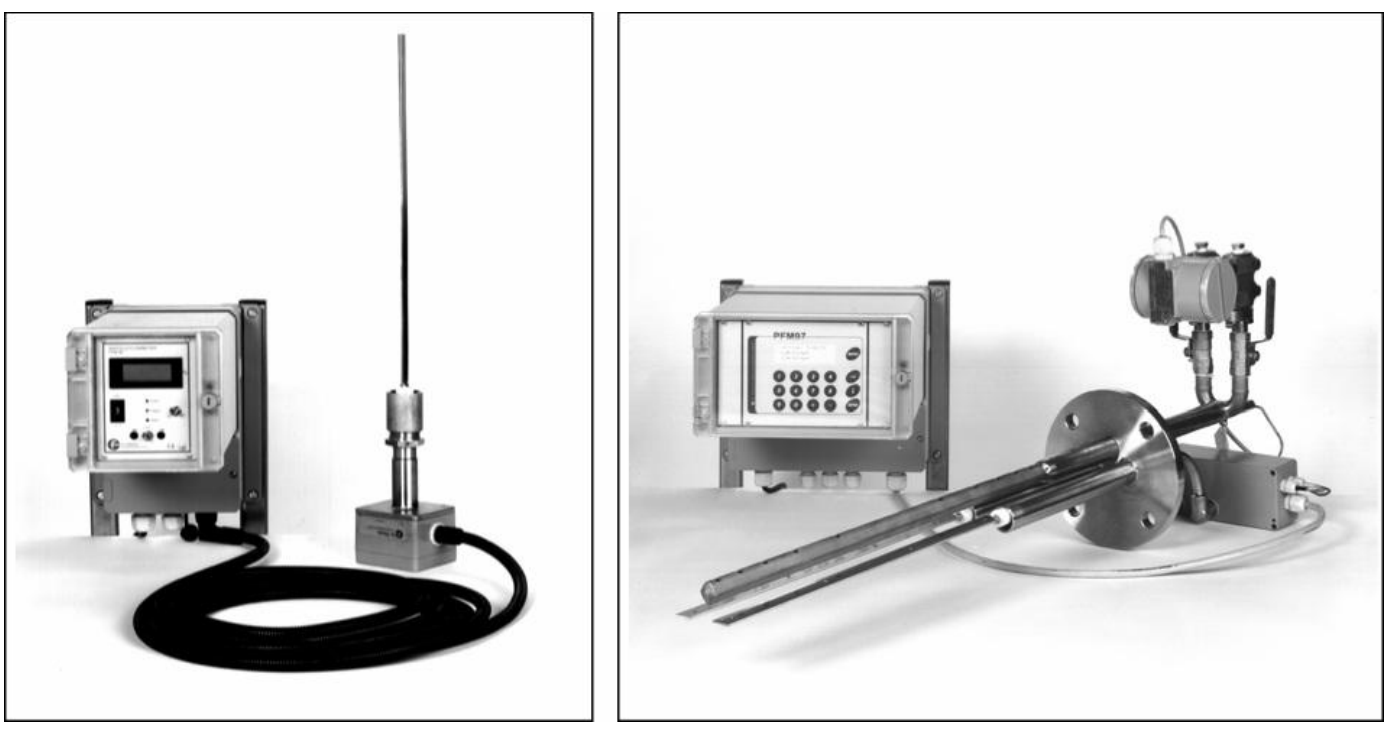

Figure 2. Triboelectric type measuring devices

The radioisotope method of measuring dust concentration is based on the property that radioactive radiation ( $\beta$ usually--radiation) is absorbed by dust particles. The mass of trapped dust is determined by the degree of attenuation of radioactive radiation as it passes through the accumulated dust layer.

The results of radioisotope measurements of dust concentrations depend to some extent on the chemical and dispersive composition, which is due to the non-linearity of the specificity of the interaction of radioactive radiation with the substance and the degree of absorption.

Practice shows that the application of dust meters is different and they are divided into two groups: the first - used in the workplace, the second - industrial waste. Devices with a smaller measurement range are used to certify workplaces to achieve results that are more accurate. The concentration of dust in this area should be controlled, as large amounts of dust in the workplace can adversely affect the health of workers working in such conditions and cause a number of respiratory illnesses. Recently, more and more large factories have begun to think about the exhaust gases they produce. In addition to environmental monitoring using stationary gas analysis stations, dust emissions are also monitored.

\section{REFERENCES}

1. Fundamentals of Life Safety: Textbook /

2. V.I.Kozachenko, B.Yu. Koltsov, L.A. Neiman, B.I. Popov.SpbGAAP, St. Petersburg, 1994, $82 \mathrm{p}$.

3. V.M. Elterman. Air protection at chemical and oil refineries. M., Chemistry, 1985, 160 p.. 
CURRENT RESEARCH JOURNAL OF PEDAGOGICS 2(12): 166-170,

December 2021 DOI: https://doi.org/10.37547/pedagogics-crjp-02-12-33

ISSN 2767-3278

(C)2021 Master Journals

Crossref doi) 81 Google

Accepted 25th December, 2021 \& Published 30 ${ }^{\text {th }}$ December, 2021

4. M.A Pinigin, IK Ostapovich. Prognosis of morbidity of the population according to the integrated indicator of atmospheric air pollution. In the collection "Problems of prenosological hygienic diagnostics". L., 1989, p. 177.

5. Pinigin M.A. Hygienic bases for assessing the total air pollution in populated areas. Hygiene and sanitation, 1985, N1, pp.6669.

6. Klimova D.M., Kutepov E.N. Changes in health status at different levels of air pollution. In the collection "Problems of prenosological hygienic diagnostics". L., 1989, p. 129.

7. Peregud E.A., Gorelik D.O. Experimental methods for monitoring atmospheric pollution. L., Chemistry, 1981.

8. Becker A.A., Agaev T.B. Protection and control of pollution of the natural environment. L., Gidrometeoizdat, 1989.

9. Klimenko A.P. Methods and instruments for measuring dust concentration. M., Chemistry, 